\title{
TOLEHO
}

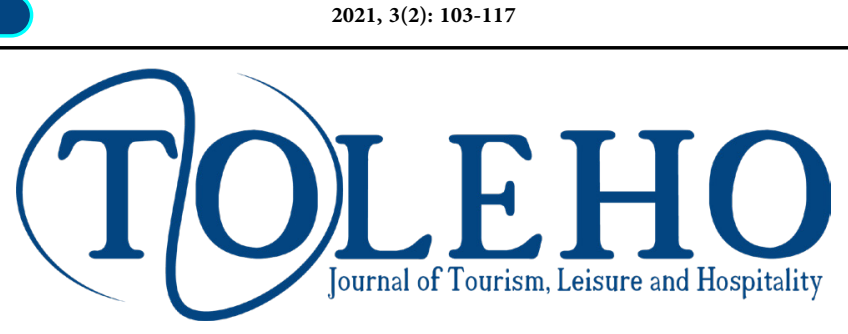

\section{PANORAMIC MUSEUM VISITS AS CULTURAL RECREATION ACTIVITIES: PANORAMA 1453 HISTORY MUSEUM EXAMPLE}

Fatmanur Kübra Aylan ${ }^{\text {a, }}$, Hatice Sarı Gök ${ }^{\mathrm{b}}$

${ }^{\mathrm{a}}$ Recreation Management Department, Tourism Faculty, Selçuk University, Konya, Turkey.

ORCID: 0000-0002-6703-2934 / e-mail: kubraceliloglu@gmail.com

${ }^{\mathrm{b}}$ Department of Travel, Tourism and Entertainment Services, Yalvaç Vocational School, Isparta University of Applied Science, Isparta, Turkey. ORCID: 0000-0003-0949-2593 / e-mail: haticesarigok@isparta.edu.tr

\begin{tabular}{l} 
KEYWORDS \\
\hline Leisure \\
Recreation \\
Panorama Museums \\
Postmodern Museology \\
Visitor Experience
\end{tabular}

Visitor Experience

\begin{abstract}
Museums have moved to a different dimension as a result of the development of revolutionary new insights in classical collection exhibitions and the use of new technologies, with the understanding of Post-Modern Museology. Panorama museums, which are developing as three-dimensional storytelling models of history museums and becoming increasingly common, are museums of different designs due to their exhibition conditions with their $360^{\circ}$ panoramic painting art. Panorama museums are innovative museums open to technology and interactive platforms that provide visitors with one-to-one interactive experience. Museums, as a recreational activity, are also among the points of visit for cultural purposes. Especially with its architectural features and designs, it gives visitors the impression of living that moment in a historical film, giving them a completely different world feeling. Based on this, the visitor experiences of the "Panorama 1453 History Museum" on the TripAdvisor were analysed using content analysis method. The universe of the research consists of 473 comments made by people who visited the museum between December 2011 and August 2020. The sample of the research, on the other hand, consists of the first 141 visitor comments. The remaining 232 comments were not included in the study because they consist of the comments made to the first posts. A total of 795 encodings were made in the research. In the research, it was found that the visitors were satisfied with the panorama museum visits as a recreational activity, it contributed to the learning of history and culture, they also experienced a historical journey and found it interesting and impressive. In the conclusion part of the research, suggestions were made in terms of both academic and sectoral aspects.
\end{abstract}

\section{Introduction}

Time is defined as the duration that a work or phenomenon occurs, will occur (Turkish Language Association, 2020). When time is examined from different angles for people, it consists of three parts. The first of these is the "time to exist" that people spend to meet biological needs such as eating and drinking, sleeping and cleaning. The second is the "livelihood (working) time" aimed at maintaining life such as working, securing the future, producing, and the third is "leisure time" for making use of the existing time such as leisure, recreation, hobby, play and the time left over from working time (Demirdağ, 2019: 29). Today, people spend their free time with various activities in order to relax, be happy and have a good time in order to get away from negative emotions and stressful environments they are in due to work or other factors (Munusturlar, 2016). Among these activities, museum visits have an important place in leisure activities. Museums are places that make visitors happy and provide a pleasant time with the effects such as cultural development of the person, spending quality time, living the moment, witnessing the history.

Leisure activities that increase satisfaction and happiness feelings can correct many negative conditions (physical, psychological and health) of the participating individuals (Leversen, Danielsen, Birkeland \& Samdal, 2012). Similarly, recreational activities, which are leisure activities, enable individuals to be relieved of the troubles in their lives, relax and develop themselves, while positively affecting themselves, their relationships and sociocultural adaptation (Patry, Blanchard \& Mask, 2007).

Post-Modern Museology understanding gradually leads to the development and use of revolutionary new insights in classical collection exhibitions (Doğan, 2018). This transformation in museums has created post-modern museums. Museums in Turkey are classified as archeology museums, art museums, history museums, ethnography museums, natural history and geology museums, military museums, industrial museums, specialty museums and science museums according to their exhibitions (Madran,

${ }^{\star}$ Corresponding Author.

Received 03.02.2021; Received in revised form 09.05.2021; Accepted 13.05.2021 This article is licensed under a Creative Commons Attribution 4.0 International License. e-ISSN: 2687 - 3737 / ㄷ 2021 The Authors. Published by Anadolu University. http://dx.doi.org/10.48119/toleho.873719 
1999). Panorama museums are three-dimensional storytelling models of history museums that are widespread today. Panorama museums have different design and exhibition methods compared to other museums in terms of exhibition conditions and functional requirements since they involve 360 degree panoramic painting art (Ediz, 2019). Panorama museums are architecturally designed in cylindrical and spherical forms. With the domed shells, panorama museums are able to give visitors the feeling of another world (Zülfikar, 2020: p. 66). As the main idea, they were created with the logic of taking a photograph of or simulating "that moment or situation" (Ediz \& Akıncıtürk, 2018). There is also a high demand for panorama museums. For example, Panorama 1453 History Museum was visited by 795.018 in $2014,715.246$ in 2015, 590.812 in 2016, 570.177 in 2017, 578.158 in 2018 and 577.515 in 2019 (Kültür A.Ș. Annual Report, 2019).

As a result of the field scan it was seen that panorama museums were studied in terms of architectural features (Maraşlıoğlu, 2019), contemporary exhibition methods, vision and designs (Zülfikar, 2020), virtual tour experience (Taşkıran \& Kizllırmak, 2019). However, it was found that the experiences of people who visited the panorama museums were not investigated. Based on this, the aim of the study was established as determining the visitor experiences for panorama museum tours as a cultural activity. For this purpose, in this study, Panorama 1453 History Museum was chosen as the research area, as it is the first panoramic museum in Turkey, has a full panoramic feature and has the highest number of comments on the TripAdvisor site. The research started on January 2021, and it was determined that there were 473 comments made between December 2011 and August 2020 about the Panorama 1453 History Museum on the Tripadvisor site. 141 of these comments were shared by the visitors, and the remaining 232 comments consist of the comments made to the first posts For this reason, the sample of the research consists of the first 141 posts made. A total of 795 encodings were made in the research. According to the results of the research, the panorama museums contribute to the visitors as a cultural recreational activity area in terms of providing historical witnessing and teaching history and culture with animation techniques (3D hall, simulation, 3D display, electronic guide, effects and sounds related to the conquest, etc.). It has been determined. In addition, online comments were mostly found to be (136 satisfaction) satisfaction. The study is important in terms of examining the visitor experiences by considering the panorama museums as a cultural recreation activity area.

\section{Conceptual Framework}

\subsection{Recreation and Cultural Recreation Activities}

The concept of "recreation", derived from the Latin word "recreatio", was used to mean "regaining health" and later "regenerating the individual for work" (Torkildsen, 1992: 64; Edginton, Hanson \& Edginton, 1992: p. 4). In short, recreation, which means regeneration, restructuring and re-creation, is commonly used as a leisure time in its Turkish equivalent (Şahin \& Kocabulut, 2014:p. 47). In the literature the concept of recreation becomes diversified as recreation as a need; the activities that the individual does to ensure his / her inner satisfaction, recreation as a leisure activity; activities people participate in their spare time, recreation as a value for the individual and society; activities that the individual does for others rather than himself/ herself and recreation in the sense of re-creation; activities in which individuals participate in order to provide mental and physical calmness (Torkildsen, 2006: p. 49-50).

It is seen that recreation activities are classified based on different aspects in the field literature (Mieczkowski, 1990; Jensen, 1995; Bell, 2001; Edginton, Hudson, Dieser \& Edginton, 2004; Mull, Bayless \& Jamieson, 2005; Plummer, 2008; Hazar, 2014; Munusturlar, 2016). In general, recreation activities are classified according to the number of participants, spatial differences, demographic characteristics, functional aspects, time and way of participating in the activities. Cultural recreation activities are activities carried out under the classification (according to their purpose (functional)) as, semi-active recreation (according to the type of action), indoor recreation (according to the place).

Culture is a complex set of relationships that includes knowledge, beliefs, traditions, artistic activities, moral values, law, other abilities and habits gained by a person as a member of a society (Kottak, 2001: p. 46). Culture, which is one of the primary elements that make up today's society, is a set of human-made values (Giddens, 1998: p. 26). In this respect, culture in social sciences can be defined as expected behaviors with a set of common values and norms (Lažnjak, 2011: p. 1012). Therefore, cultural values are learned by observing, listening, talking and interacting with different cultures or societies. With cultural recreational activities, groups belonging to different cultures can be brought together in common recreational areas and have similar experiences.

All activities created to spend leisure time according to the traditions and customs, knowledge, beliefs and moral values of a nation are defined as cultural recreational activities (Gül, 2014: p. 60). Cultural recreation is all kinds of leisure activities aimed at improving the knowledge and skills of the participants (Hacioğlu, Gökdeniz \& Dinç, 2009: p. 41; Hazar, 2014: p. 45; Dalkılıç, 2017: p. 24). Every day, participation in cultural recreation activities is increasing (Beyers, 2007: p. 25). Activities organized by municipalities, associations, educational institutions and foundations, courses of visual arts, crafts, foreign language, painting, dance, music, theater courses, vocational courses, visits 
to museums and art galleries can be examples of cultural recreational activities.

Cultural activities can be carried out as many leisure activities according to their types and characteristics (Mclean \& Hurt, 2012: p. 3). In addition, the cultural structures of societies are extremely effective on recreational activities. All over the world, people love to spend their free time dancing, singing, sculpting, handicrafts and decorating their homes. Cultural resources (museums, historical buildings, archaeological sites, etc.) help societies to embrace their own cultural identity and to understand cultural diversity and richness. In this way, they contribute to the general functioning of the society. Because cultural resources give visitors the opportunity to get to know other cultures and their own culture, to see cultural artifacts, to participate in activities, to taste local foods and to share traditions (Kurar, 2019: p. 135). In this context, museum visits are considered among recreational activities and allow people to improve their cultural background.

\subsection{Panaroma Museums}

Museums are democratizing, inclusive and polyphonic spaces for critical dialogue about the past and the future. By accepting and addressing today's conflicts and difficulties, museums secure the artifacts and samples they are obliged to protect on behalf of society for future generations, and ensure equal access to this cultural heritage by people from all walks of life. Museums are not profit making organizations. They are participatory and transparent, and are defined as organizations that contribute to human dignity, social justice, global equality and global welfare, and work in active partnerships with various communities to protect, research, interpret, exhibit and develop works in order to better understand the world (ICOM, 2019). Museums have undergone enormous changes both functionally and physically over the centuries. Today, museums have become organizations that are far beyond the institutions that exist only with their collections, protect, research and exhibit them.

The presentation of social memory and cultural diversity by using new technological tools increases the interest in museums day by day. In this context, studies in the field of digital museology continue at full speed. Panorama museums that convey the artistic and archaeological accumulation of the country through a kind of chronology or storytelling theme can be given as an example of digital museum work in Turkey (Bostancl, 2019: 38). Panoramas consist of setups built partly with painting and partly with models. It is used in historical, military, geology and natural history museums especially to add value to the narrative (Erbay, 2009: p. 142). Panorama museums are designed as places that allow a 360-degree virtual tour through panoramic photography. It gives the impression of living in a historical movie and living that moment. Panorama museums are innovative museums open to technology and are interactive platforms that provide visitors with one-to-one interactive experience (Bostancl, 2019: p. 38).

Panorama, is defined as narrative continuous scenes in visual arts or the state of the earth painted on a flat or curved background (Zülfikar, 2020: p. 49). The architectural structures that played an important role in the birth and development of panorama art are panorama museums. Robert Barker (17391806) was the inventor of the term panorama and was instrumental in the emergence of panorama museums. Although Barker initially made panorama exhibitions mobile, over time he wanted his works to be exhibited permanently. As a result, Barker built a rotanda (round or oval structure or room with a domed top in classical architecture) named "the Panorama" in London's Leicester Square (Hyde, 2015: p. 39). A total of 126 panoramas between 1793 and 1861 (closed from 1861) were displayed on the Leicester Square Panorama (Wilcox, 1976; Hyde, 1988: p. 58). Barker changed his panorama about once a year. The eighth panorama exhibited in the grand hall was the panorama of "Istanbul View from Galata Tower" opened on April 27, 1801. The panorama of Istanbul was exhibited between 1801 and 1803 and Istanbul was the first foreign city to be shown on the Leicester Square Panorama (Maraşlıoğlu, 2019: p. 25). The second panorama of Istanbul, "Istanbul View from the Maiden's Tower", has been on display on the second floor of the Leicester Square Panorama starting from 23 November 1801 (Hyde, 1988: p. 39).

Most of the panorama museums were built in the 1800 s with the oil painting technique where the event took place. These are half panoramic museums built vertically or horizontally. The most important panoramic museums include Waterloo Battle Panorama, Sivastopol Panorama (telling of the Ottoman-Russian war), Napoleon's Moscow Battle Panorama, Mesdag Panorama (the oldest panorama museum open to visit) and Plevne Defense Panorama (describing the Russian-Turkish war) (www.kultur. istanbul/panorama-1453-muzesi/). There are approximately 32 panoramic museums in the world (Kültür A.Ş. Annual Report, 2019: p. 24).

Museum experiences that are considered as tourist experiences are a transition or exchange between the museum and its visitors (Roppola, 2012). Sheng and Chen (2012) discussed the experience expectations of museum visitors in their study; They identified it as comfort and entertainment, cultural entertainment, self-identification, escape and historical remembrance. It has been determined in the studies that museum experiences differ according to the demographic characteristics of the visitors and the dimensions of the experience also affect the visitor satisfaction (Sheng \& Chen, 2012; Lee \& Smith, 2015; Kırcova \& Erdoğan, 2017). When the field studies carried out in the studies related to panorama museums are examined, it is seen that Maraşlıoğlu (2019) discussed with an analysing 
approach the Panorama 1453 History Museum which is open to audience with his "complete panorama" presentation which he developed using examples of panorama museums from Turkey and around the world. Zülfikar (2020) examined the "Panorama 1326 Museum and Interaction Center" in his study. In the study, he prepared a proposal model for the museum. This proposal model has been prepared in line with contemporary museology principles and aims to bring a new vision and design to museology literature, museum architecture and contemporary exhibitions. Taşkıran \& Kızılırmak (2019) examined customer experiences with experiential marketing and technology use in virtual environment in their study.

\subsection{Panorama Museums in Turkey}

Museums and similar structures have assumed the role of "external disk" of urban memory. Panorama museums, which contain the history of the city, historical buildings, and views of the cities or nature, are more meaningful, more emotional structures that citizens can connect with (Ediz, 2019). Panoramic museums are usually built to chart certain events in history. Panorama museums in Turkey are among the places worth seeing in terms of telling the historical events and keeping them alive. Panorama museums open to visitors in Turkey are Panorama 1326 Bursa Conquest Museum, Samsun 1919 Panorama Museum, Panorama 1453 History Museum, Konyanüma Panorama Museum, Kahramanmaraș Liberation Panorama Museum, December 25 Gaziantep Defense Heroic Panorama and Museum (Figure 1). Information about these museums is listed below.

Panorama 1453 History Museum; Panorama 1453 History Museum was opened to visitors in 2009 in Topkapı Culture Park in Istanbul. The panoramic museum that depicts the conquest of Istanbul in three dimensions is a first in Turkey. In the museum, where the latest technological possibilities are used, the conquest of Istanbul is animated with light and sound effects with a historical panorama that can be seen from all directions with a 360 degree angle (Kültür A.Ş. Annual Report, 2019: p. 24). There is a panoramic route in the first section of the museum, which consists of two main sections. Panorama 1453 Permanent Exhibition, which is prepared permanently, is located on this route. There are modern miniature works that start with the foundation of Istanbul, depict the siege and conquest of Istanbul, the life of Mehmed the Conqueror, the construction activities after the conquest of Istanbul and the wars with original miniature, engravings and paintings and depict the conquest with today's perspective. At the end of the exhibition, the entrance of the platform where the panoramic painting is located begins. At the end of a dark corridor, visitors are shown the moment of entering the city at dawn on May 29, 1453 (Zülfikar \& Ediz, 2020: p. 83).

Panorama 1453 History Museum is a fully panoramic museum in both horizontal and vertical plane. The sky, starting from the upper part of the picture, extends in the form of a dome in an uninterrupted way. In this way, although it is a closed space since there are no references to grasp the reality and dimensions, the starting and ending points are not available, the visitor feels a three-dimensional outdoor feeling thanks to the atmosphere of the panorama when entering this area (Maraşlıoğlu, 2019: p. 46). It is a place worth seeing with its panoramic ceiling, three-dimensional parts and sound effects. The museum, which is established on an area of $3000 \mathrm{~m} 2$, looks like a 360-degree painting without borders and when viewed, it creates a threedimensional effect. In order to achieve the threedimensional effect, the viewer was allowed to look at the picture from a platform 14 meters away. The $650 \mathrm{~m} 2$ area of the painting is three-dimensional and there are imitations of cannons, gun carriages, powder barrels used in the siege of the area. The two-dimensional painting area of $2350 \mathrm{~m} 2$ starts right after the three-dimensional zone. There are 1304 paintings and around ten thousand figures in the work (Erbay, 2011: p. 103).

Panorama 1326 Bursa Conquest Museum; In order to create a recreation area in Bursa city center, a "History Park" project with the empire city theme was implemented. After the implementation, thematic gardens containing historical elements were built in the area called "Kamberler History and Culture Park". In the field, the "Panorama Bursa 1326 Conquest Museum" project of which the chief consultant was Prof. Dr Halil İnalcık (Oğuzoğlu, 2015: p. 137) was completed in 2018. The project, which stands out with the slogan of "History Project Preserving the Green", is aimed to be one of the symbolic structures of the city (Toprakoğlu \& Durak, 2020: p. 137). The domed structure is a semi-dome structure with 40 meters exterior, 38.2 meters inner diameter (Zeynalov, 2018 cited in Maraşlıoğlu, 2019: p. 48) and a height of 14 meters from the visitor platform to the top of the picture. It is larger than Panorama 1453 History Museum with its 2.450 $\mathrm{m} 2$ picture area, $700 \mathrm{~m} 2$ three-dimensional model area and $3150 \mathrm{~m} 2$ image area. In order to apply the painting to the inner hemisphere, a rotating scaffold with one leg fixed in the middle and the other two legs movable circumferentially was designed. The museum, whose ceiling was built in the form of an ellipsoidal dome, is the second full panoramic museum in the world built after the Panorama 1453 History Museum (Maraşlıoğlu, 2019: p. 48).

Samsun 1919 Panorama Museum; It is a museum that digitally reveals the foundation of the Independence Struggle, Veteran Mustafa Kemal's first step, how it was in how our struggle for independence has been carried out since the beginning, and displays pictures of Samsun of that day, and depicts the struggle for independence in 1919. Samsun Panorama 1919 Museum, which was opened to visitors in 2018, draws attention with its 
formal setup. In the design, with the reorganization of one of Samsun's important squares, the sports hall has been re-functionalized as the Digital Display Center and Panorama Museum, and includes digital displays and dioramas describing Atatürk's arrival in Samsun (Zülfikar \& Ediz, 2020: p. 84). The concept of diorama consists of the Greek words dia, which means "from one end to the end" and -orama meaning "scene-landscape". Diaromas, whose main purpose is to give the viewer a sense of movement and time with different light and filter systems, are used in the design of panorama museums (Böcekler, 2015: p. 139). Visitors are not in the position of spectators in this museum, but feel themselves in the middle of the War of Independence with the special film technique, sound effects and viewing method (Doğan, 2018).

Konyanüma Panorama Museum; Konyanüma Panorama Museum was opened for service by Konya Metropolitan Municipality in 2017. It has an intermediate form with a cone ceiling, which is not fully panoramic and, unlike its examples in Europe, to which the sky is partially added. In addition, there are very realistic and one-to-one silicon human sculptures brought from abroad in the field of models. In the panoramic view of Konya in the middle of the 13 th century, it gives the opportunity to the visitor to witness the life of Mevlana, the turning points of his life and the life of that period in which everyone was living in a cosmopolitan city as in peace (Maraşlıoğlu, 2019: p. 50-51). When entered through the main entrance door which was built based on the Seljuklu crown doors, there are miniatures of 25 Mevlevi lodges from Turkey and around the world (Balkans, Middle East, Mecca, Medina, Cairo, Crimea) in the open court in the middle (Konya Metropolitan Municipality, 2019). The 17 domes surrounding the courtyard represent the Mevlana Lodge. It is reached by two entrance gates named Mevlana and Şems, and two stairs from the courtyard to the museum section. On the embossed panel created between the entrances, there are symbols and motifs used by the Seljuk State (www.tarihikentlerbirligi.org, 2019: p. 46-47).

Kahramanmaraş Liberation Panorama Museum; Kahramanmaraş Liberation Panorama Museum was opened in 2018, the 98th anniversary of the liberation of Maras from the enemy occupation, in order to tell the Maraş national struggle that sparked the liberation of the occupied Anatolian lands after World War I and to immortalize the liberation struggle on February 12, 1920. The museum is located in the Kültür Park within the Kahramanmaraș Onikişubat district. In the museum, the struggle for liberation is first described in a normal screening and then in a 3D animated film (Kahramanmaraş Metropolitan Municipality, 2020). The exhibition scenes in the museum are made with oil painting portraits of the prominent heroes of the War of Independence and the weapons used in that period exhibition and the representation of the celebrations on February 12,
1920, with the Kiosks of the Independence Medal and voice narrations (Kahramanmaraş Metropolitan Municipality, 2020).

December 25 Gaziantep Defense Heroism Panorama and Museum; The "25 December Gaziantep Defense Independence Heroic Panorama and Museum", built by Gaziantep Metropolitan Municipality and telling every moment of the defense of Antep, was opened in 2020 on the 99th anniversary of the city's liberation from enemy occupation. The struggle of Antep against the enemy for 11 months is re-experienced with all the details. In the museum, unlike other examples, not a single memory but a long process is portrayed. In addition, in the museum, all aspects of the heroic Antep Defense are explained with the area consisting of 14 paintings, 3 dioramas and a panoramic oil painting of 13 meters in height and 120 meters in length by the Russian painter Aleksander Samsonov. In addition, the artifacts used during the war period are also exhibited in the museum (Gaziantep Metropolitan Municipality, 2020).

\section{Methodology}

Qualitative research method is a concept that includes the attitudes and strategies followed in qualitative research that aims to understand how people understand, experience, interpret and produce the social world (Sandelowski, 2004: p. 893). The most frequently used research techniques in qualitative research can be listed as in-depth interview, focus group interview, unstructured (uncontrolled) observation, semi-structured observation, case study, document review, life history, oral history, and grounded theory (Gönç Şavran, 2014: p. 87). In this study, document analysis technique was used, and secondary data were utilized. Secondary data are data collected for different purposes or by people other than the researcher, they can be used to extend existing research (Given, 2008: p. 803). In this study, it is aimed to examine the experiences gained as a result of the visits to the panorama museums, which emerged with the post-modernism museum understanding, as a cultural recreational activity. In line with this purpose, Panorama 1453 History Museum was chosen as the research area because it was opened for the first time in Turkey, it is a full panoramic museum in both horizontal and vertical planes and it has the most comments on the TripAdvisor. Accordingly, 473 comments about Panorama 1453 History Museum shared on TripAdvisor.com by visitors to the museum between December 2011 and August 2020 were reviewed. 141 of these comments were shared by the visitors and the remaining 232 comments consist of the comments made to the first posts. For this reason, the sample of the research consists of the first 141 posts made. When the data of study were examined, it was determined that there were expressions about the field of cultural recreational activity (Figure 2) and the visitor satisfaction status (Figure 3). These 


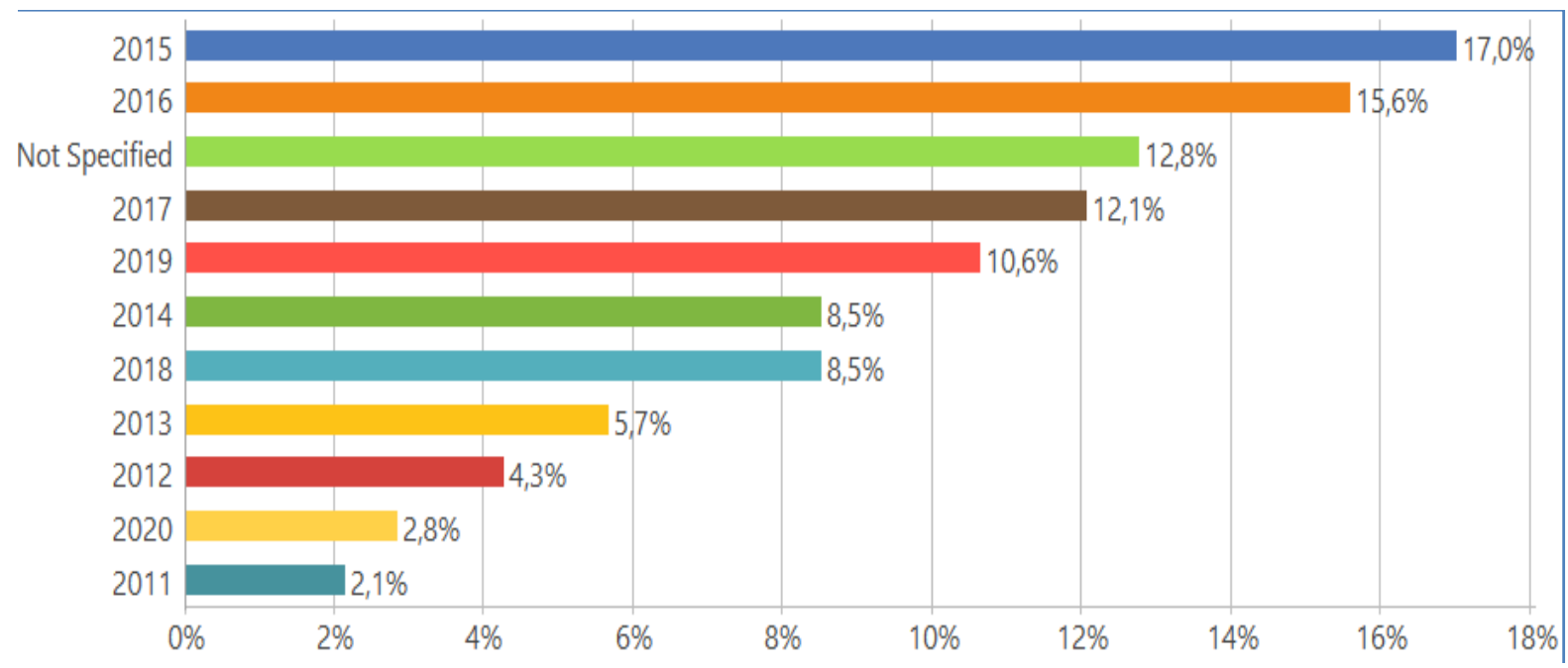

Graph 1. Distribution of the Visitors' Posts on the TripAdvisor for the 1453 Panorama History Museum by Years

expressions were subjected to content analysis and coded and themed. During the analysis phase, all the data obtained were documented and analyzed by content analysis method (Ylldırım \& Șimșek, 2013: p. 259-260). In content analysis, there are stages such as coding data, finding themes, organizing codes and themes, defining and interpreting the findings in the processing of data obtained through document analysis (Ylldırım \& Şimșek, 2006). The obtained data were analyzed systematically by transferring them to the qualitative data analysis program "MAXQDA 2018". The MAXQDA program helps you analyze various data such as interviews, reports, tables, online surveys, focus groups, videos, audio files, literature, images, PDFs (MAXQDA, 2020). In this study, code count, frequency and percentage analysis and visual mapping methods in which the relationships between codes and categories are visualized were used as the unit of analysis.

In order to calculate the consistency rates of the codes created in the study, the data were coded by two independent coders. This coding was done by other people in a "blinded" manner, unaware of the expectations and questions of the researcher (Creswell, 2013: p. 253). The consensus among the coders was calculated as $81 \%$ using the formula "consensus / (consensus + disagreement) x $100 "$ proposed by Miles and Huberman (1994).

\section{Results and Discussion}

\subsection{Frequency Distributions}

Graph 1 shows the distribution rates of the posts shared by the visitors for 1453 Panorama History Museum by yearsIt is seen that the first comment about the museum opened in 2009 was made in 2011. Afterwards, sharing rates increase with the increasing number of visits. As can be seen in the graph, the most posts were shared in 2015 with a rate of $17 \%$ (24 shares). Due to the decrease in visits due to the Covid-19 outbreak in 2020, the number of comments made this year has decreased to almost the same rate as in 2011.

Graph 2 shows the distribution rates of the posts shared by the visitors for 1453 Panorama History Museum by the types of visit. In the posts, it is seen that $44.9 \%$ (62 shares) mostly did not specify the type of visit. It was determined that among those who specified the type of visit, $24.1 \%$ (34 posts) were visited with their families the most, and the least was 3.5\% (5 posts) for business visits.

\subsection{Titles}

As seen in Figure 1, the terms conquest, panorama, history, experience, impressive, Istanbul are used the

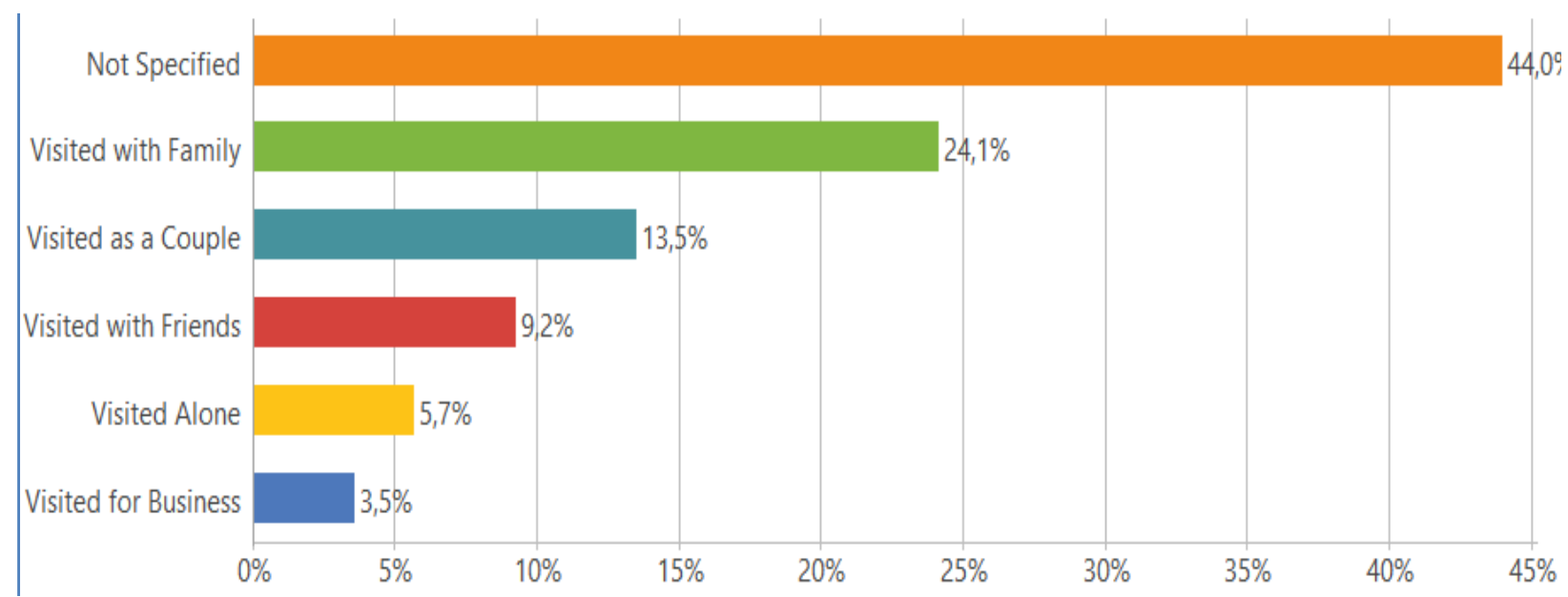

Graph 2. Distribution of the Visitors' Posts on the TripAdvisor for the 1453 Panorama History Museum by the types of visit 


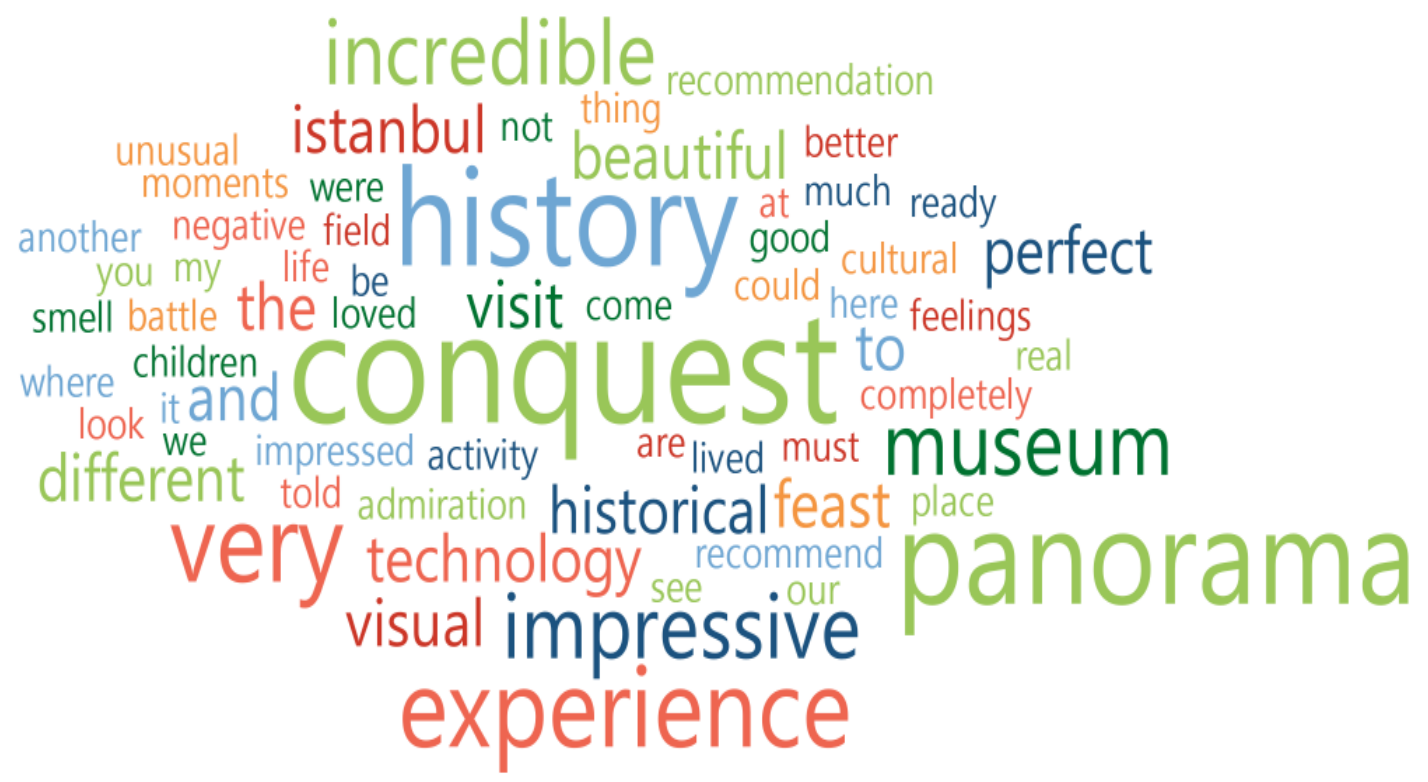

Figure 1. Word Cloud Analysis of the Titles of the Visitors' Posts on the TripAdvisor for the 1453 Panorama History Museum

most. İstanbul; "1453 Panorama Visit in Istanbul" (2019). "The last day in Istanbul" (2017). "Visiting point in Istanbul" (2016). Panorama; "1453 Panorama Visit in Istanbul" (2019). "Panorama exhibition" (2017). "Incredible technology" (2014). "Very well designed" (Not Specified). "Excellent workmanship" (Not Specified). History; "Live the history" (2018). "An enthusiastic history museum" (2016). "A good look at our history" (2016). "Conquest is not told and it is lived" (2016). "History smell" (2015). "Reliving history" (2015). "A historical visit" (2014). "For those who want to experience the spirit of conquest" (2013). "Conquest Istanbul" (Not Specified). Admiration; "It's great" (2017). "Visual feast" (2015). "Beautiful" (2015). "Very Impressive" (2014). "Interesting As It Is Different" (2014). "Pride" (2014). "An amazing experience" (2013). "Magnifical" (2014). "We were very impressed" (2013). "Great Atmosphere" (2013). "Incredible" (2011). "I loved it" (Not Specified). Recommendation; "A must see museum" (2019). "You Will Not Regret" (2015). "Must go" (2015). Negative; "A small museum" (Not Specified).

\subsection{Panorama Museum Tour as a Cultural Recreational Activity}

In Figure 2, the distribution of the posts of the visitors for the panorama museum tour as a cultural recreational activity is given according to the themes. Visitor posts under the category of "Panorama Museum Trip as Cultural Recreational Activity" were classified under the themes "Learning History and Culture" and "Witnessing History". These themes are divided into sub-themes according to visitor expressions, and sub-themes are divided into subthemes according to their subjects. There are 68 statements on the theme of "Learning History and Culture" and 112 statements on the theme of

\footnotetext{
${ }^{1}$ Visitor code
}

${ }^{2}$ Year of sharing
"Witnessing History". The main theme of "Learning History and Culture" consists of 58 statements. Under this main theme, 5 expressions formed the subtheme of "Educational Trips". The expressions about the theme of educational trips that are especially beneficial for children are discussed under the subtheme "For Children".

The main theme of "Witnessing History" consists of 31 visitor expressions. Under this main theme, there is "Animation" sub-theme with 18 expressions. The animation sub-theme is also divided into 8 subthemes under the title of animation techniques as "3D Hall" (3 statements), "Simulation" (1 statement), "3B Exhibition" (6 statements), "Electronic Guide" (8 statements), "Effects/Sounds Related to Conquest" (24 statements), "Pictured Related to Conquest" (19 statements), "Video Related to Conquest" (1 statement) and "Written Information Related to Conquest" (1 statement).

\subsection{Learning History and Culture}

"You can learn the history of the city you are in by visiting the museum located in Topkapı district of Istanbul, a rare museum where the conquest of Istanbul by Fatih Sultan Mehmet in 1453 is animated with sound and visuals" $\left(\mathrm{Z3}^{1}, 2020^{2}\right)$. "They reflected the conquest of Istanbul and the effects of this conquest on Istanbul in great detail" (Z47, 2016). "When you first enter the museum, you start seeing the conquest of Istanbul with the visuals on the walls, the main movie starts when you climb the spiral staircase. You cannot recover for 1-2 minutes. What a magnificent picture it is, unbelievable, I congratulate all those who contributed" (Z46, 2015). "The conquest of Istanbul is narrated. It's a visual feast. The text and pictures describing the history are in the museum section in the entrance" (Z66, 2015). "An unexpected atmosphere and a magnificent virtual sky await you. The conquest of Istanbul can only be enlivened so well after centuries. If you love our history and history in general, you must definitely visit" (Z81, 2014). "People 


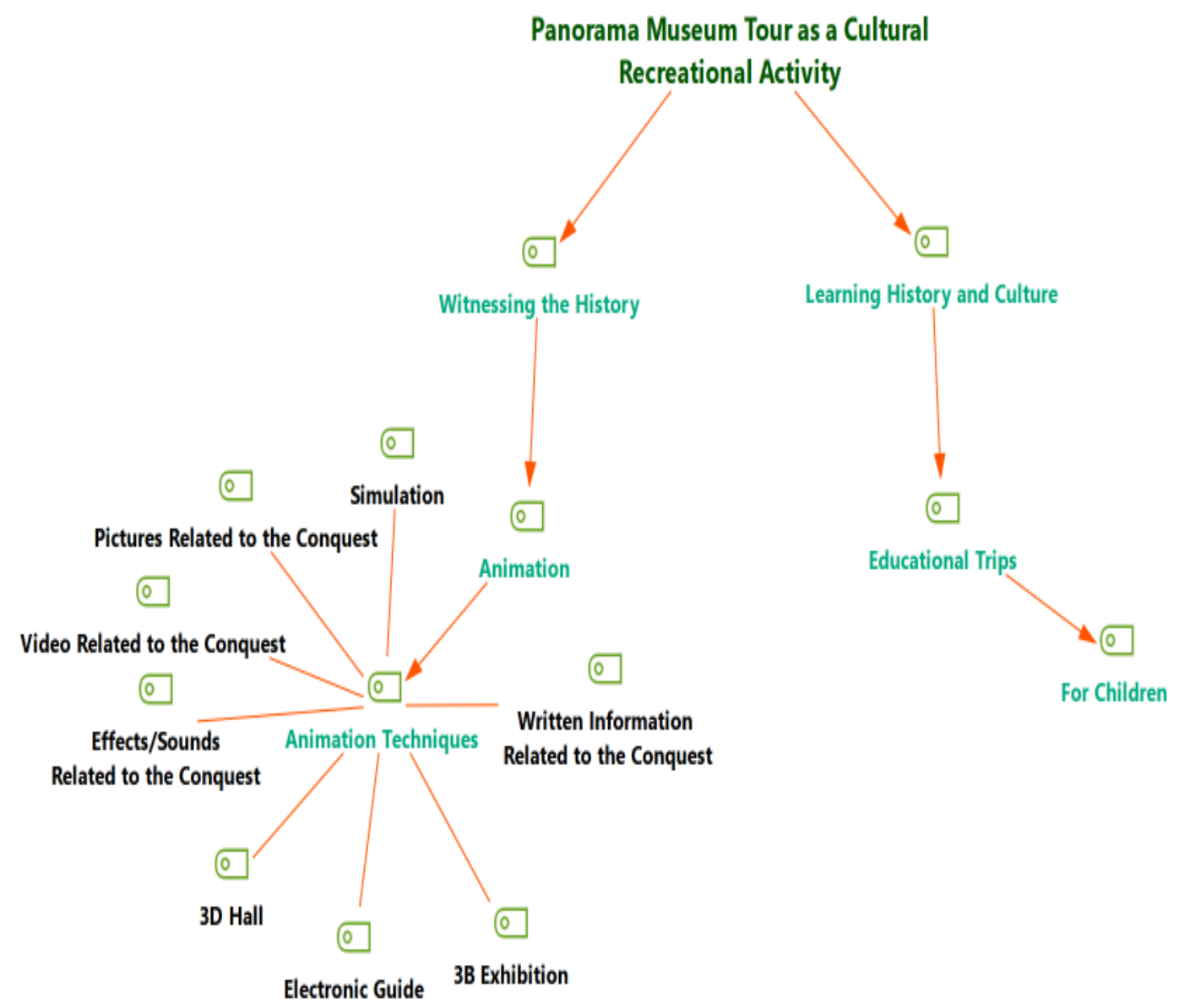

Figure 2. Classification of the Visitor Satisfaction Status of the Visitors' Posts on the TripAdvisor Site for the 1453 Panorama History Museum by the Number of the Coded Section

who are interested in history, especially Ottoman history, should see it" (Z74, 2014). "It is a must-see detail that will provide you with some information about the conquest of Istanbul, with great details. The 360 degree panoramic view also fascinates you" (Z61, 2014). "An excellent museology to explain the conquest of Istanbul and the opening of an era to people of all levels with high technology" (Z112, Not Specified).

\section{Educational Trips}

"Panorama 1453, which we came with 8th grade students on our school trip, was very beautiful. I never guessed it would be done this way. They animated it almost exactly with sound effects, visuals and models. Thank you to the owner of the idea and to those who made it" (Z44, 2016). "We went many times with students, it is a very beautiful and different work, the place to be seen, especially you should find the Fatih silhouette hidden by the artists in the clouds on the ceiling" $(\mathrm{Z38}, 2016)$. "It's kind of like the power of visual education" (Z72, 2015). "1453 Conquest is told, a useful place for students" (Z66, 2015). "This museum, which we went to on a school trip, is very impressive with the scene of the conquest of Istanbul. The detailed siege of conquest is interesting. Explanatory information about the conquest is given in the tables on the walls between floors" (Z86, Not specified)
For Children; "They have succeeded in shedding light on history with such a beautiful and impressive decor. Don't forget to take the kids (Z15, 2018). This lovely museum is great for kids with its history" (Z124, 2017). "We wanted to visit cultural places that could be beneficial for children during our Istanbul trip and Panorama 1453 was at the top of our list. The children were very impressed, we liked it very much, the threedimensional images were very successful. I think it should be seen" (Z43, 2015). "Ten thousand human figures are drawn. Especially ideal for children" (Z43, 2015).

\subsection{Witnessing the History}

"A beautiful museum for those who want to experience the conquest of Istanbul (Z14, 2019). You can feel yourself in the war" $(\mathrm{Z} 41,2019)$. "A museum among the trees right next to the walls, the artists trying to make everything look like reality make you feel like you are in history, you need to go see it and get that feeling" $(\mathrm{Z} 17,2018)$. "Those who want to experience the conquest must definitely see it. You find yourself in the middle of the conquest" (Z51, 2016). "You feel yourself in a 360 degree war" (Z65, 2015). "It is recommended to be seen at least once and to relive history vividly" (Z59, 2015). "A perfect place. You can feel the conquest of Istanbul again" (Z63, 2015). "It is a very interesting and beautiful 
museum where the conquest of Istanbul is described with a panoramic picture. Panorama 1453 was recently built. It's realistic as if you were watching the conquest of Istanbul in the middle of the war. Sound effects are provided. Very beautiful and interesting" (Z83, 2014). "The person feels proud and feels like he lived that moment" $(\mathrm{Z75}, 2014)$. "It is a great place for those who want to experience the conquest of Istanbul up close. It was designed really well" (Z89, 2013). "An atmosphere of conquest is given in the museum. Everywhere from the earth to the sky gives the impression of 1453. It seems as if Fatih Sultan Mehmet will appear in a moment, it was a very nice work, worth seeing (Z79, Not specified). If you want to live the conquest of Istanbul once again" (Z111, Not Specified).

\section{Animation}

"It is the place where the conquest of Istanbul is animated in the Istanbul Topkapı district, with pictures and effects and videos" (Z2, 2020). "This museum, which tells about the conquest of Istanbul, has been very good. The animations are very nice. A place that smells of history so abundantly" (Z19, 2018). "As you enter inside, your eyes look completely different, your ears hear completely different. There is a very good animation show inside. I suddenly found myself in a state of war, and cannons and rifles exploded with sounds. In short, it is very nice to tell history in this way, to make it feel, thanks to those who made it" $(\mathrm{Z73}, 2015)$. "A place that transforms the moments of conquest of Istanbul into sound, breath and image (Not Specified). They portrayed the conquest of Istanbul in 360 degrees. Nice work. (Z101, 2011). The animations inside are beautiful" (Z104, 2011). "Soldiers, horses, sultans ... They thought and designed everything perfectly (Z107, Not specified). A real battle field. A real place, a war museum. Unlimited space, sounds, atmosphere are very exciting. Imagination is high, you feel like you're at war!" (Z135, Not Specified).

Animation Techniques

3D Hall; "At the entrance of the museum, written and visual themes that give historical information about the conquest welcome you, on the last floor there are visuals that you will admire, and you feel as if you are living those moments exactly with the $3 D$ sound system to better reflect the war on the walls" (Z28, 2017). "Capture depiction of 1453 real combat and $360^{\circ}$ Constantinople in $3 D$ and very lifelike images" $(\mathrm{Z77}, 2014)$.

Simulation; "This is a historical animation hall that smells of heroism through the eyes of the Ottoman Empire. Historical sculptures, paintings, narrations. The $7 D$ simulator at the entrance is quite enjoyable; I recommend to try it. It can change your view of life" (Z49, 2015).

3D Exhibition; "We walked to a large park to reach the panorama. Upon entering, you will be surrounded by a $3 D$ view of the battle with sound effect. You can see the historical wall outside" (Z116, 2019). "This small museum opened in 2009, where the conquest of Istanbul is animated in $3 D$ and receives quite a lot of visitors" (Z62, 2015). "It is a wonderful place that reveals all the details of the conquest from the moment you first enter, makes you feel like you are in the middle of a war with $3 D$ drawing and is supported by the sounds of cannons, swords and horses" (Z85, 2014). "Those who want to experience the conquest of Istanbul in 3D with sound should definitely go" (Z75, 2014).

Electronic Guide; "They give headphones for a fee to listen to the historical story, and they narrate you in front of each Picture" (Z6, 2019). "If you prefer, you can get an electronic guide inside for a low price" (Z64, 2015). "Do not forget to take a headset at the entrance from the door, it will be very useful to guide you inside" (Z79, Not specified).

Effects/Sounds Related to the Conquest; "It is a place where the conquest of Istanbul is told. Supported with sound effects" (Z4, 2020). "The conquest of Istanbul is described with pictures and sound effects. It's realistic, it's beautiful. They give headphones for a fee to listen to the historical story, and they narrate you in front of each Picture" (Z6, 2019). "With panoramic ceiling painting, the Conquest of Istanbul is kept alive both visually and audibly through ball sounds" (Z36, 2016). "You find yourself directly in the conquest of Istanbul. The atmosphere, the sounds, the place are beautiful" $(\mathrm{Z} 42,2016)$. "The music and sound system created an ambience that really enlivens the environment and adds vitality" (Z100, 2012). "An exemplary museum with everything, the Conquest of Istanbul in 1453 could only be felt in an atmosphere in which it was described with such a magnificent painting, sound, light and objects, it could not be done better" (Z91, Not specified). "A place that transforms the moments of conquest of Istanbul into sound, breath and image" (Z101, Not Specified).

Pictures Related to the Conquest; "The conquest of Istanbul is presented with pictures and sound effects" (Z7, 2019). "It was picturesque and detailed, with many drawings, especially the ceiling and sky" (Z113, 2019). "It is a great place, there are panels and pictures on the walls at the first entrance" (Z11, 2019). "It was designed very nicely, the setting is really beautiful, the paintings are better than those of the painters who are considered the most important in the World" (Z29, 2017). "When I saw the paintings in which the conquest process was animated, I realized that the sky was also a painting" (Z48, 2015).

Video Related to the Conquest; "It is the place where the conquest of Istanbul is animated in the Istanbul Topkapı district. Demonstration is made with pictures, effects and videos" (Z3, 2020).

Written Information Related to the Conquest; "At the entrance of the museum, written and visual themes that provide historical information about the conquest welcome you" $(\mathrm{Z28}, 2017)$.

\subsection{Visitor Satisfaction Status}

In Figure 3, it is seen that the visitor satisfaction status is examined under two themes: satisfaction 


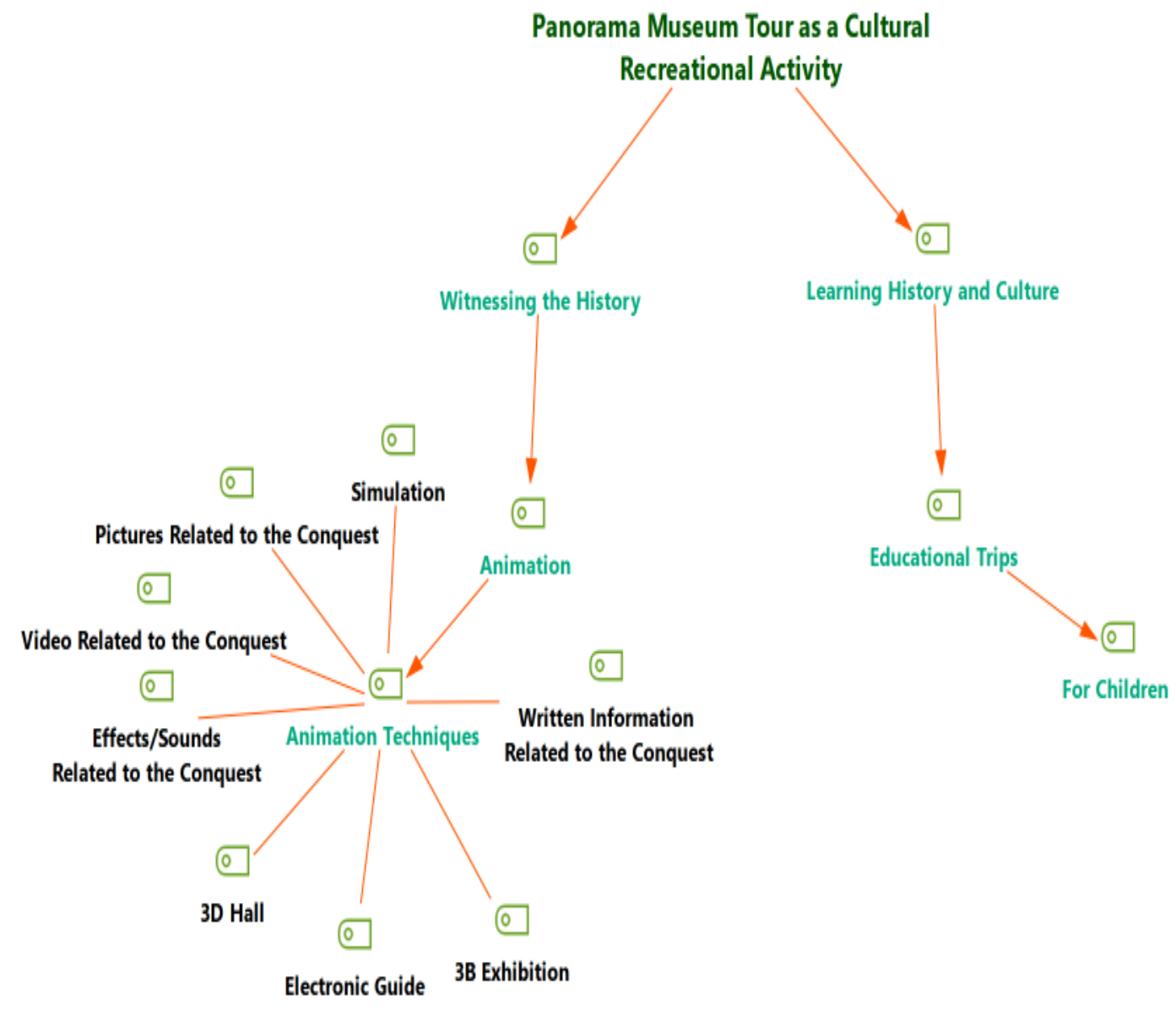

Figure 3. Classification of the Visitor Satisfaction Status of the Visitors' Posts on the TripAdvisor Site for the 1453 Panorama History Museum by the Number of the Coded Section

and dissatisfaction. While there are 136 statements about satisfaction, there are 50 statements about dissatisfaction. It has been determined that visitor posts mostly contain admiration expressions.

\section{Satisfaction Status}

Admiration; "It is a perfect design. A beautiful museum for those who want to experience the conquest of Istanbul" (Z14, 2019). "It was the first time we went as a family. A really different ambience, a different environment, people are fascinated. It is a small place but it is really well thought out" (Z29, 2017). "It was designed very nicely, the setting is really beautiful, the paintings are better than those of the painters who are considered the most important in the world, I liked it very much as a person who saw the Louvre museum abroad" (Z57, 2016). "I liked everything, the colors and drawings are great" (Z104, 2011).

Souvenirs; "You can make commemorative coin inside" (Z30, 2017). "There is a gift shop and a souvenir coin vending machine" (Z42, 2016).

Easy Accessibility; "Transportation is very easy with metrobus and rail system from anywhere" (Z51, 2016). "Transportation is very easy by metro or tram" (Z60, 2015).

A recreative activity; "A museum that you can visit as a family and must be seen" (Z63, 2015). "We wanted to visit cultural places that could be beneficial for children during our Istanbul trip and Panorama 1453 was at the top of our list. The children were very impressed, we liked it very much, the threedimensional images were very successful, I thought it would be a bigger area, I found it a bit small compared to what I thought" $(\mathrm{Z} 43,2015)$. "It is an indispensable destination if a cultural trip is to be made in Istanbul. First of all, it is an absolutely indispensable stop to understand the spirit of Istanbul" (Z92, 2013).

-Dome Design; "What matters is the panoramic dome that completely surrounds you and covers your field of vision. The sights and sounds enliven the event, but the real highlight is the painted background that gives a true meaning of the mechanics of the battle with over 10,000 figures" (Z118, 2019). "A magnificent dome design" (Z34, 2017). "Panorama 1453 Museum is a new and very modern museum. The conquest of Istanbul is the most interesting part of the panoramic dome representing the 1453 conquest by Fatih Sultan Mehmet" (Z138, Not Specified).

Reasonable Price; "The entrance fee is very affordable" (Z27, 2017). "The entrance fee was a very small amount of 5 TRY" $(\mathrm{Z138}, 2016)$. "I found the museum fee very reasonable" (Z48, 2015).

Impressive; "The museum located around Topkapl is really impressive. Although it has a small area, you can feel you are climbing up to sky through a dark staircase. You will encounter an area that enlivens the 
battlefield and surrounds you. You must experience this" $(\mathrm{Z35}, 2016)$. "I did not expect such a place. The moment you step in, you are truly enchanted" (Z72, 2015). "When you step onto this platform in the museum, you may experience a shock that will last for 10 seconds" (Z81, 2014). "It is a truly extraordinary experience, the animations are beautiful" (Z105, 2011). "Once inside, it is not easy to go upstairs and not be impressed by that magnificent ceiling. It makes people dizzy officially" (Z104, Not specified).

Interesting; "Topkapı's mess ended thanks to this museum and that region has great potential. The museum is quite interesting and definitely worth visiting" (Z37, 2016). "Looking up while finishing the stairs, I suddenly found myself surrounded by clouds. I couldn't perceive it for a few seconds and thought I was outside. Then, when I saw the paintings in which the conquest process was animated, I realized that the sky was also a painting. It was a very interesting moment. The pictures are incredibly successful and realistic" $(\mathrm{Z} 48,2015)$.

Recommendation; "No one should miss out on this amazing experience $(\mathrm{Z114}, 2019)$. It is definitely one of the places to visit" $(\mathrm{Z65}, 2019)$. "It is a great loss that people living in Istanbul or who somehow come to Istanbul have not seen Panorama 1453" (Z78, 2015). "It is definitely one of the places to see" (Z78, 2015). "It is among the must-see places in Istanbul (Z84, 2013). I recommend everyone to see, Perfect place to see" (Z111, 2012).

\section{Dissatisfaction Status}

Distance/Transportation; "It is not an easily accessible place due to its location" (Z22, 2018). "Interesting place to see, however it is too far away" (Z138, Not specified).

Crowded; "There can be a lot of queues for visits on busy days" (Z41, 2016). "It receives crowds of visitors" (Z62, 2015). "When it is very crowded, one feels confused while wandering. Therefore, it is better to visit when it is empty" $(\mathrm{Z73}, 2015)$.

Absence of Simulation/Animation; "There is no animation, only a half-sphere sized picture on the walls of the place, you try to listen with headphones. Better read from the book, no need to get tired" (Z10, 2019). "I think it should be enriched more visually" (Z18, 2017). "Some movies, animations would be great but are missing here." (Z130, 2015).

Artifacts; "I am not sure about the originality of the items put there" (Z22, 2018).

Not accepting prepaid/museum card; "It is a bit bad that it does not accept museum card, but it is very good overall" $(\mathrm{Z23}, 2018)$. "It is a disadvantage not to enter with a museum card" $(\mathrm{Z} 21,2018)$.

Being small physically; "The museum was very nice, but the inside was a little small, it could have been a larger museum" $(\mathrm{Z} 19,2018)$. "A small museum in Topkapi $(Z 21,2018)$. We went with great expectation, it was a little small" (Z40, 2017).

\section{Conclusion}

Museum visits, which are among the recreational activities in which people participate voluntarily according to their interests, are among the cultural recreations. Museum visits contribute to communities' getting to know their own culture and history, embracing cultural identity and increasing cultural accumulation. Panorama museums, which are designed in accordance with the Post-Modern Museology concept, carry the understanding of museology far beyond exhibiting classical collections. Functions such as keeping pace with the developing technologies, digitalization, and providing interactive experiences to the visitors are increasing the visitor interest in panorama museums day by day.

In the research, 141 comments made by people who visited the museum on TripAdvisor.com website about "Panorama 1453 History Museum" were analysed. The highest number of shares was made in 2015 with $17 \%$ (24 shares). It is seen that the first comment about the museum was made in 2011Comments were shared at an increasing rate from 2011 to 2015 , and it was determined that there was a decrease in the number of comments in the years after 2016. When the types of visits of the commentators are examined, it is seen that those who visit with their families with a rate of $24.1 \%$ and as a couple with a rate of 13.5 Visitor experiences have been analyzed under two categories: "Panorama Museum Trip as Cultural Recreative Activity" and "Visitor Satisfaction". Under the category of Panorama Museum Trip as a Cultural Recreational Activity, there are 112 statements on the themes of "Witnessing History" and 68 statements "Learning History and Culture". There are expressions about the animation technique in the museums "3D Hall, Simulation", "3D Display", "Electronic Guide", "Conquest Related Effects / Sounds", "Conquest Pictures", "Conquest Video" and "Conquest Written Information". Although the comments shared about the visitor satisfaction status mostly included satisfaction (136 statements), it was determined that there were also comments containing dissatisfaction (50 statements). Expressions of satisfaction; It is easy to access, it is a recreational activity, the dome design, the price is affordable, the opportunity to buy souvenirs, and it is impressive. In case of dissatisfaction, crowd, distance / transportation, lack of simulation / animation, being paid (museum card not passing), small physical area can be given as examples.

When the studies on museums in the literature were examined, it was found that there were similar and different results with the related study. Korkmaz (2020) examined the Troya Museum electronic visitor comments in terms of service features, satisfaction and advice. In line with this study, it has been determined that the visitors are satisfied with the museum visitors. The dissatisfaction issues determined by Zanibellato et al. (2018) in their study on their museum visit experiences on TripAdvisor have been different with this study. 
The museum experience of the visitors is addressed in terms of entertainment, escape, education, culture, exploration and history. In the study, visitors' statements stating that panorama museum tours are a tool to learn about culture and history are as follows; "A rare museum where the conquest of Istanbul by Fatih Sultan Mehmet in 1453 is animated with sound and visuals, you can learn the history of the city you are in by visiting the museum located in Topkapı district of Istanbul" (2020). In the study, learning history and culture, education, witnessing history, and animating dimensions were determined as the dimensions of the museum experiment. Similarly, Sheng ve Chen (2012) discussed the dimensions of reminder, culture, animation, and education in his study.

In his study, Bostancl (2019) stated that the panoramas are made up of mechanisms that are partly composed of pictures and partly models, and that they are used in historical, military, geological and natural history museums especially to add value to the narrative. Similarly in the study There is a statement of "Istanbul is already a great city. Panorama 1453 is a historical museum that must be seen. There are panoramic images that look real, and the sounds of cannons, bullets, swords. War scenes, historical images in which the Ottoman Empire fought heroically. It was amazing, I recommend you go see it" (2016) .

Clauzel et al. (2016) examined online comments of museum visitors and museum service features; They examined it in three dimensions as basic elements, support services and ambience. The ambiance of the museum building, which includes architecture, layout, presentation and other environmental factors, provides visitors with a different experience. Two studies are similar at this point. For instance, "As you enter inside, your eyes look completely different, your ears hear completely different. There is a very good animation show inside. I suddenly found myself in a state of war, and cannons and rifles exploded with sounds. In short, it is very nice to tell history in this way, to make it feel, thanks to those who made it"(2015). Bostancr (2019) stated in her study that she gave the impression of living that moment in a historical movie, and there are expressions supporting this result in the study.

Büyükșalvarcı, Balı \& Ay (2018) examined museum visits as a cultural recreation activity in their work. Also in this study, visitors' statements stating that panorama museum visits should be considered as cultural recreational activities are as follows; "Go with your family, see it and most importantly, experience that atmosphere by feeling the history. It is a very good achievement for Istanbul" (2014). "An interesting and beautiful museum where you can spend your time on a rainy Istanbul day. The figures are very elaborate, the panoramic view really gives you the feeling of being there. Transportation is very easy by metro or tram. I recommend it" (2015). Oettermann (1997: p. 103) mentioned in his study that the panorama museums are places that allow the audience to have a good time and learn something, and to travel somewhere else.

As a result of the research, a few suggestions are made to both the industry and the academy below:

- Based on the visitor's comments about the small size of Panorama 1453 History Museum, increasing the simulation / animation applications and expanding them physically will increase visitor satisfaction.

- Since panorama museums are both a cultural recreational activity area and an important element of attraction in destination marketing, it is necessary to increase their promotional activities and to prepare their own websites with detailed and up-to-date information.

- It is seen that panorama museums in Turkey mainly reflect historical elements. In order to diversify these museums, panorama museums should be built on natural history and geology.

- In future studies, an examination can be made with new technological tools to determine the emotions that panorama museums evoke in the people who visit them.

\section{References}

Bell, S. (2001). Design For Outdoor Recreation Second Edition, Midas Printing, China.

Beyers, W. B. (2007). Cultural and Recreational Industries in Rural America: Opportunities for State Legislators. The Journal of Regional Analysis \& Policy, 37 (1), 25-27.

Bostancı, M. (2019). Dijital Müzecilik ve interaktif iletişim: SFMOMA ve MORi Dijital Sanat Müzesi Örneklemleri [Digital Museology and Interactive Communication: SFMOMA and MORI Digital Art Museum Examples]. UNIMUSEUM, 2 (2), 34-39.

Böcekler, B. (2015). Louıs-Jacques-Mandé Daguerre ve Charles Marı Bouton'un Dioraması ve Tarihsel Kökenleri [The Diorama of Louis-Jacques-Mandé Daguerre and Charles Marie Bouton and Its Historical Origins]. Sanat Tarihi Dergisi, 24 (2), 139-160.

Büyükşalvarcı, A., Balı, S., and Ay, E. (2018). Kültürel Amaçlı Rekreasyon Faaliyeti Olarak Uşak'ta Müze Ziyaretleri [Museum Visits in Uşak as a Cultural Purpose Recreation Activity]. Eurasian Academy of Sciences Eurasian Business \& Economics Journal, 16, 113-126.

Clauzel, A., Riché, C. and Vidal, M. (2016). Visitors'continental origin and museum experience: Anintercultural approach of online reviews. Revue Française $d u$ Marketing, 256, 41-59.

Creswell, J. W. (2013). Nitel Araştırma Yöntemleri, Beş Yaklaşıma Göre Nitel Araştırma ve Araştırma Deseni [Qualitative Inquiry and Research Design: Choosing Among Five Approaches] (Çev. Ed. Bütün M. ve Demir, S. B). Ankara: Siyasal Kitapevi.

Dalkılıç, G. (2017). Otel işletmelerinde Rekreasyon ve Boş Zaman Değerlendirmeleri [Recreation and Leisure in Hotel Businesses]. Master Thesis, Arel University Institute of Social Sciences, İstanbul.

Demirdağ, A. Ş. (2019). Otel Işsletmelerinde Rekreasyonel Liderliğin Iş Etiğine Etkisi: Animasyon Personeli Üzerine 
Bir Uygulama [The Effect of Recreational Leadership on Business Ethics in Hotel Businesses: An Application on Animation Personnel]. PhD Thesis, Gazi University Institute of Social Sciences, Ankara.

Doğan, S. (2018). Müzecilikte Dijital Dönüşüm Değişen Müze Teknolojileri ve Ulusal Bilgi Politikası [Digital Transformation in Museology, Changing Museum Technologies and National Information Policy]. KAM18 Kongresi Sunumu, from www.kamkongresi.com, (Retrived 10.10.2020)

Edginton, C. R., Hanson, C. J., and Edginton, S. R. (1992). Leisure programming: concepts, trends and professional practice (2nd ed.). Dubuque, IA: Brown and Benchmark.

Edginton, C., R., Hudson, S., Dieser, R., B., and Edginton, S., R. (2004). Leisure programing- a service centered and benefits approach. New York: Mc Graw Hill Companies.

Ediz. Ö., and Akıncıtürk, N., (2018). Panorama 1326 Müze ve Etkileşim Merkezi [Panorama 1326 Museum and Interaction Center]. from http://www.arkiv.com.tr/ proje/panorama-1326-muze-etkilesim-merkezi/9269 (Retrived 10.11.2020).

Ediz, Ö., (2019). Bursa Panorama Müze ve Etkileşim Merkezi [Bursa Panorama Museum and Interaction Center]. Uludağ Üniversitesi Mimarlık Fakültesi, Bursa.

Erbay, F. (2009). Müze Yönetimini Kurumsallaştırma Çabası (1984-2009) [The Effort to Institutionalize Museum Management (1984-2009)]. Mimarlık Vakfi Enstitüsü, İstanbul.

Erbay, M. (2011). Müzelerde Sergileme ve Sunum Tekniklerinin Planlanması [Planning of Exhibition and Presentation Techniques in Museums]. Beta Basım, İstanbul

Gaziantep Metropolitan Municipality, (2020). From https:// www.gaziantep.bel.tr/tr/tarihi-ve-kulturel-eserler/ gaziantep-savunmasi-ve-kahramanlik-panoramamuzesi., (Retrived 17.11.2020).

Giddens, A. (1998). Modernliğin Sonuçları. (Çev. E. Kuşdil), Ayrınt Yayınları, İstanbul.

Given, L.M. (2008). The Sage Encyclopedia of Qualitative Research Methods, SAGE Publications, Inc, Chicago.

Gönç Şavran, T. (2014). Nicel Ve Nitel Araltirmalarda Kullanılan Araştırma Teknikleri, Sosyolojide Araştırma Yöntem ve Teknikleri [Research Techniques Used in Quantitative and Qualitative Research, Research Methods and Techniques in Sociology]. (Edt. Temmuz Gönç Şavran) T.C. Anadolu Üniversitesi Yayını No: 2641.

Gül, T. (2014). Rekreasyon Olgusuna Genel Yaklaşım [General Approach to Recreation]. Ali Yaylı (Ed.), In Rekreasyona Giriş [Introduction to Recreation]. Detay Yayıncılık, Ankara.

Hacıoğlu, N., Gökdeniz, A., and Dinç, Y. (2009). Boş Zaman ve Rekreasyon Yönetimi; Örnek Animasyon Uygulamaları [Leisure and Recreation Management; Sample Animation Applications]. Detay Yayıncılık, Ankara.

Hazar, A. (2014). Rekreasyon ve Animasyon [Recreation and Animation]. Detay Yayıncılık, Ankara.

Hyde, R. (1988). Panoramania!: Art and Entertainment of the All-Embracing View, Trefoil Publications and Barbican Art Gallery Publication, Londra

Hyde, R. (2015). Dictionary of Panoramists of the English - Speaking World, The Bill Douglas Cinema Museum (University of Exeter).

ICOM, (2019). From https://icom.museum/en/resources/ standards-guidelines/museum-definition/, (Retrived 10.11.2020).

Jensen, C. R. (1995). Outdoor Recreation in America (Fifth Edition). USA: Human Kinetics.

Kahramanmaraş Metropolitan Municipality, (2020). Kahramanmaraş Kurtuluş Destanı Panorama Müzesi, from https://kahramanmaras.bel.tr/kahramanmaraskurtulus-destani-panorama-muzesi, (Retrived 19.10.2020)

Kırcova, i.., and Erdoğan, H. H. (2017). Müze Deneyimi Boyutları: İstanbul Oyuncak Müzesi Örneği. Uluslararası iktisadi ve Idari Incelemeler Dergisi (16. Uik Özel Sayısı), 649-664.

Konya Metropolitan Municipality, (2019). Konyanüma Panorama Müzesi, from https://www.konya.bel.tr/ haberayrinti.php?haberID=6887, (Retrived 20.10.2020).

Korkmaz, H. (2020). Troya Müzesi Elektronik Ziyaretçi Yorumlarının Hizmet Özellikleri, Memnuniyet ve Tavsiye Açısından Incelenmesi [Evaluation of Troya Museum Visitors' Electronic Reviews In Terms of Service Quality, Satisfaction and Recommendation]. Gastroia: Journal of Gastronomy and Travel Research, 4(1), 43-56.

Kottak, C. P. (2001). Antropoloji, Insan Çeşitliliğine Bir Bakış, Ütopya Yayınevi, Ankara

Kurar, i. (2019). Kültür, Rekreasyonel Deneyim, Tercihleri ve Memnuniyet Arasındaki ilişski: Alanya Örneği [The Relationship Between Culture, Recreational Experience, Preferences and Satisfaction: The Case of Alanya]. PhD Thesis, Akdeniz University Institute of Social Sciences, Antalya.

Kültür A.Ş. Annual Report, (2019). From https://kultur. istanbul/gorsel/2021/01/2019_Faaliyet-Raporu.pdf (Retrived 10.11.2020).

Lažnjak, J. (2011). Dimensions of National Innovation Culture in Croatia: Content Validity of Hofstede's Dimensions, Istraživanja/Journal for General Social Issues, 20(4(114)), 1015-1038.

Leversen, I., Danielsen, A., G., Birkeland, M., S., and Samdal, O. (2012). Basic Psychological Need Satisfaction in Leisure Activities and Adolescents' Life Satisfaction. J Youth Adolescence, 41, 1588-1599.

Lee, H. M., and Smith, S. L. (2015). A Visitor Experience Scale: Historic Sites and Museums. Journal of China Tourism Research, 11(3), 255-277.

Madran, B. (1999). Müze Türleri [Types of Museums], Editör: Tomur Atagök, In Yeniden Müzeciliği Düşünmek [Reconsidering Museology]. Yıldız Teknik Üniversitesi Basım Yayın Merkezi, İstanbul, 3-19.

Maraşlıoğlu, G. (2019). Panorama 1453 Tarih Müzesi'nin Algı Olanaklarını Genişletmesi Bakımından Resim Diline Katkılarına Genel Bir Bakış [An Overview of the Contributions of the Panorama 1453 Museum of History to the Language of Painting in terms of Expanding the Possibilities of Perception]. Master Thesis, Hatay Mustafa Kemal University Social Sciences University, Hatay.

MAXQDA (Software for Qualitative and Mixed Methods Research). (2020). From, https://www.maxqda.com/ lang/tr, (Retrived 25.10.2020).

Mclean, D., and Hurt, A. (2012). Kraus' Recreation and Leisure in Modern Society. Ninth Edition, Jones \& Bartlett Publishers. 
Mieczkowski, Z. (1990). World Trends in Tourism and Recreation. New York: Peter Lang Publishing.

Miles, M. B., and Huberman, A. M. (1994). An expanded sourcebook qualitative data analysis. SAGE, London.

Mull, R.F., Bayless, K.G., and Jamieson, L. M. (2005). Recreational Sport Management, Human Kinetics, Champaign.

Munusturlar, S. (2016). Boş Zaman ve Rekreasyon Kavramı [Leisure and Recreation Concept]. Müge Akyıldız Munusturlar (Ed.), In; Rekreasyon Yönetimi [Recreation Management] (pp. 2-27), Anadolu Üniversitesi Yayınları, Eskişehir.

Oettermann, S. (1997), The Panorama: History of a Mass Medium, Zone Books, NewYork.

Oğuzoğlu, Y. (2015). Panorama 1326 Bursa "Beylikten Cihan Devletine" [Panorama 1326 Bursa "From Beylik to World State"]. Furkan Ofset, Bursa

Patry D. A., Blanchard C. M., and Mask L. (2007). Measuring University Students Regulatory Leisure Coping Styles: Planned Breathes or Avoidance. Leisure Sciences, 29, 247-265.

Plummer, R. (2008). Outdoor Recreation, Routledge, New York.

Roppola, T. (2012). Designing for the Museum Visitor Experience, Routledge, UK.

Sandelowski, M. (2004). "Qualitative Research", Lewis-Beck, M.; A. Bryman \& T.F. Liao (Ed.). In; The Sage Encyclopedia of Social Science Research Methods, Thousands Oaks: SAGE.

Sheng, C. W., and Chen, M. C. (2012). A Study of Experience Expectations of Museum Visitors. Tourism Management, 33(1), 53-60.

Şahin, i., and Kocabulut, Ö. (2014). Sportif Rekreasyon Faaliyetlerine Düzenli Katılımı Engelleyen Faktörlerin Incelenmesi: Akdeniz Üniversitesi, Turizm Fakültesi Öğrencileri Üzerine Bir Araşttrma [Investigation of the Factors that Prevent Regular Participation in Sports Recreation Activities: A Study on Students of Akdeniz University, Faculty of Tourism]. Journal of Recreation and Tourism Research (JRTR), 1 (2), 46-67.

Tarihi Kentler Birliği Müze Özendirme Yarışması, (2019), from https://www.tarihikentlerbirligi.org/wp-content/ uploads/TKBMuzeOzendirmeYarismasi_2019_.pdf, (Retrived 18.10.2020).

Taşkıran, Ö., and Kızıırmak, İ., (2019). Deneyimsel Pazarlama Kapsamında Sanal Turların Müze Ziyaretlerine Etkisi: Panorama 1453 Örneği [The Effect of Virtual Tours on Museum Visits in the Scope of Experiential Marketing: Panorama 1453 Example]. Uygulamalı Sosyal Bilimler Dergisi, 3 (1), 1-19.

Toprakoğlu, H., K., and Durak, S. (2020). Bursa'da Kentsel Gelişime Yön Verme Amacıyla Düzenlenmiş Mimarlık Yarışmaları [Architecture Competitions Organized with the Purpose of Directing Urban Development in Bursa] Paradoks Ekonomi, Sosyoloji ve Politika Dergisi, 16 (1), 119-145.

Torkildsen, G. (1992). Leisure and Recreation Management, 3. Edition, London.

Torkildsen, G. (2006). Leisure and Recreation Management (5th. ed.). USA: Routledge

Turkish Language Association (2020). Zaman, from https:// sozluk.gov.tr/, (Retrived 12.11.2020).
Wilcox, S. B. (1976). The Panorama and Related Exhibitions in London, University of Edinburgh, Master's Thesis.

Yıldırım, A., and Şimşek, H. (2006). Sosyal Bilimlerde Nitel Araştırma Yöntemleri [Qualitative research methods in the social sciences]. Ankara: Seçkin Yayıncılık.

Yıldırım, A. and Şimşek, H. (2013). Sosyal Bilimlerde Nitel Araştirma Yöntemleri [Qualitative research methods in the social sciences]. Ankara: Seçkin Yayıncılık.

Zanibellato, F., Rosin, U., and Casarin, F. (2018). How the Attributes of a Museum Experience Influence Electronic Word-of-Mouth Valence: An Analysis of Online Museum Reviews. International Journal of Arts Management, 21(1), 76-90.

Zeynalov, Y. (2018). "Konyanüma" ressamı ve "Panorama 1453" ile "Panorama 1326" figürlerden sorumlu ressam.

Zülfikar, A. B. (2020). Değişen Müze ve Müzecilikte Sergilemenin Teknoloji Boyutunun incelenmesi: Bursa Panorama Müzesi Örneği [Investigation of the Technological Dimension of Exhibiting in the Changing Museum and Museology: The Case of the Bursa Panorama Museum]. Master Thesis, Uludağ University Institute of Science and Technology, Bursa.

Zülfikar, A. B., and Ediz, Ö. (2020). Değişen Müze ve Müzecilikte Sergilemenin Teknoloji Boyutunun incelenmesi: Bursa Panorama Müzesi Örneği [Investigation of the Technological Dimension of Exhibiting in the Changing Museum and Museology: The Case of the Bursa Panorama Museum]. Lycus Dergisi, 2, 67-100.

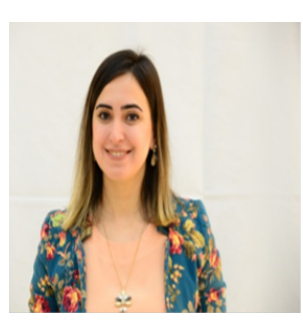

Fatmanur Kübra Aylan is an Assistant Professor in the Department of Recreation Management in Faculty of Tourism at the Selçuk University. She received her PhD and MS in Tourism Management at Selçuk University and Bachelor's degree in Hospitality Management Teaching at Nevşehir Hacı Bektaş Veli University. Dr. Aylan also worked as receptionist in tourism sector before working at university. Dr. Aylan has many academic publications (articles, conference papers, book chapters) related tourism. Her research areas include responsible tourism, recreation management and destination marketing. She also serves on the board of referees for few national and international journals.

ORCID: 0000-0002-6703-2934 


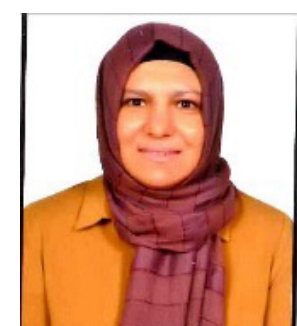

Hatice Sarı Gök was born in 01.04.1981 in

Kızılağaç neighborhood of Manavgat,

Antalya. I completed my primary education

at Kızılağaç Primary School. I completed

my secondary and high school education at

Manavgat Girls Vocational and Anatolian Vocational High School. I completed my

undergraduate education in 2004 at Gazi

University, Faculty of Commerce and

Tourism Education, Department of Travel Management and Tourism

Guidance. I completed my master's degree in 2007 at Gazi University, Department of Tourism Management Education. Gazi University and Selçuk University joint program Tourism Management completed my Ph.D. I am continuing my career as a lecturer in Isparta University of Applied Sciences, Department of Tourism Travel and Entertainment Services.

ORCID: 0000-0003-0949-2593 